\title{
Ogólnopolski system udostępniania zasobów geoinformacyjnych OGNIWO
}

\section{Anna Wrochna}

W iele instytucji geodezyjnych i kartograficznych mogących poszczycić się długoletnią działalnością przechowuje w swoich archiwach i bibliotekach unikatowe zbiory zawierające dane przestrzenne. Część z tych instytucji zachęcona efektami cyfryzacji dokłada starań by zgromadzony przez lata zasób został upowszechniony i mógł dalej służyć celom badawczym. Największą wartością takiego zasobu map, zdjęć lotniczych i satelitarnych oraz różnego rodzaju pomiarów wykonywanych w terenie była aktualność prezentowanych danych. Obecnie wartość zasobu złożonego z elementów powstałych kilkadziesiąt lub kilkanaście lat temu jest gdzie indziej - mapy, zdjęcia i wyniki pomiarów są bowiem unikatowym dokumentem przestawiającym stan miniony, zarejestrowany $\mathrm{w}$ określonym momencie. Istotną wartością tego rodzaju zasobu są dane, z których można czerpać informacje o środowisku geograficznym w określonym momencie w przeszłości, kompleksowo lub w zakresie tylko jego wybranych elementów. $Z$ tego względu dotychczasowy krąg badaczy potencjalnie zainteresowanych danymi przestrzennymi znacznie się poszerzył, między innymi o tych, zajmujących się badaniami z zakresu szeroko rozumianej geografii historycznej, historii gospodarczej i innych, dla których obserwacje wieloletnie są podstawą analiz.

Wyjątkową wartością tego zasobu jest połączenie archiwalnych danych przestrzennych z aktualnymi. Możliwość łatwego odnalezienia potrzebnej geoinformacji, następnie uzyskanie dostępu do niej oraz odpowiednie jej zastosowanie w procesie badawczym lub decyzyjnym leży u podstaw m.in. budowania społeczeństwa informacyjnego, e-administracji, europejskiej infrastruktury informacji przestrzennej INSPIRE i wielu innych programów proponowanych przez Unię Europejską.
Zasób o tak unikatowych walorach dla badaczy chcących wykorzystać historyczne dane przestrzenne, jak opisane wyżej, znajduje się w Instytucie Geodezji i Kartografii (IGiK). Gromadzony przez prawie siedemdziesiąt lat, czyli od momentu powstania Instytutu w 1945 r., jest pokłosiem prac badawczo-rozwojowych prowadzonych $\mathrm{w}$ Instytucie $\mathrm{w}$ zakresie geodezji, geodynamiki, fotogrametrii, kartografii, teledetekcji i systemów informacji przestrzennej, a także topografii i wiedzy o środowisku. Potrzeba udostępnienia tego zasobu, w tym również publikacji naukowych i wyników prac badawczych, pojawiła się w związ$\mathrm{ku} \mathrm{z}$ ich potencjalną przydatnością do badań naukowych i prac badawczo-rozwojowych w priorytetowych dziedzinach i dyscyplinach naukowych, wpisujących się w Krajowy Program Badań Naukowych i Prac Rozwojowych zatwierdzony przez Ministerstwo Nauki i Szkolnictwa Wyższego. Badania naukowe i wszelkie prace prowadzone $\mathrm{w}$ ramach tego programu mają przyczynić się do szybkiego rozwoju cywilizacyjno-gospodarczego kraju i budowy gospodarki opartej na wiedzy.

Wspomniany wyżej zasób Instytut Geodezji i Kartografii udostępnił poprzez Ogólnokrajowy System Geoinformacji Naukowej Integrujący Wiedzę Geodezyjną - OGNIWO, który powstał $w$ ramach projektu sfinansowanego z Programu Operacyjnego Innowacyjna Gospodarka w ramach Priorytetu 2: Infrastruktura sfery B+R, Działanie 2.3: Inwestycje związane $z$ rozwojem infrastruktury informatycznej nauki. Projekt realizowany był w latach 20112013. Zapewnił on środowisku naukowemu i innym potencjalnym użytkownikom stały i bezpieczny dostęp do zaawansowanej infrastruktury informatycznej, która umożliwia wykorzystanie zasobów Instytutu Geodezji i Kartografii w pracach naukowo-badawczych, 
między innymi do prowadzenia badań naukowych z zastosowaniem technologii społeczeństwa informacyjnego, a także do celów gospodarczych, edukacyjnych itp.

System OGNIWO łączy przede wszystkim użytkownika cyfrowych zasobów geoinformacyjnych $\mathrm{z}$ danymi zasobu za pośrednictwem usług sieciowych danych przestrzennych, a ponadto również zasoby geoprzestrzenne $\mathrm{z}$ infrastrukturami geoinformacyjnymi o zasięgu regionalnym, krajowym i międzynarodowym. Usługi danych przestrzennych są dostępne dla wszystkich uprawnionych użytkowników, którymi są: instytuty naukowe i badawczo-rozwojowe, placówki edukacyj- mi użytkownikami danych przestrzennych udostępnianych poprzez omawiany system są badacze zajmujący się między innymi takimi dziedzinami wiedzy, jak: rolnictwo, leśnictwo, geologia, górnictwo, ochrona środowiska, planowanie przestrzenne, transport, telekomunikacja, nawigacja, turystyka, ale również obronność i zarządzanie kryzysowe. Dostęp do danych nie wymaga od użytkownika posiadania specjalistycznego oprogramowania typu GIS, gdyż uzyskiwany on jest za pomocą typowej przeglądarki www.

Zasoby informacyjne udostępnione przez Instytut Geodezji i Kartografii obejmują terytorium całego kraju lub jego wybrane obszary, są

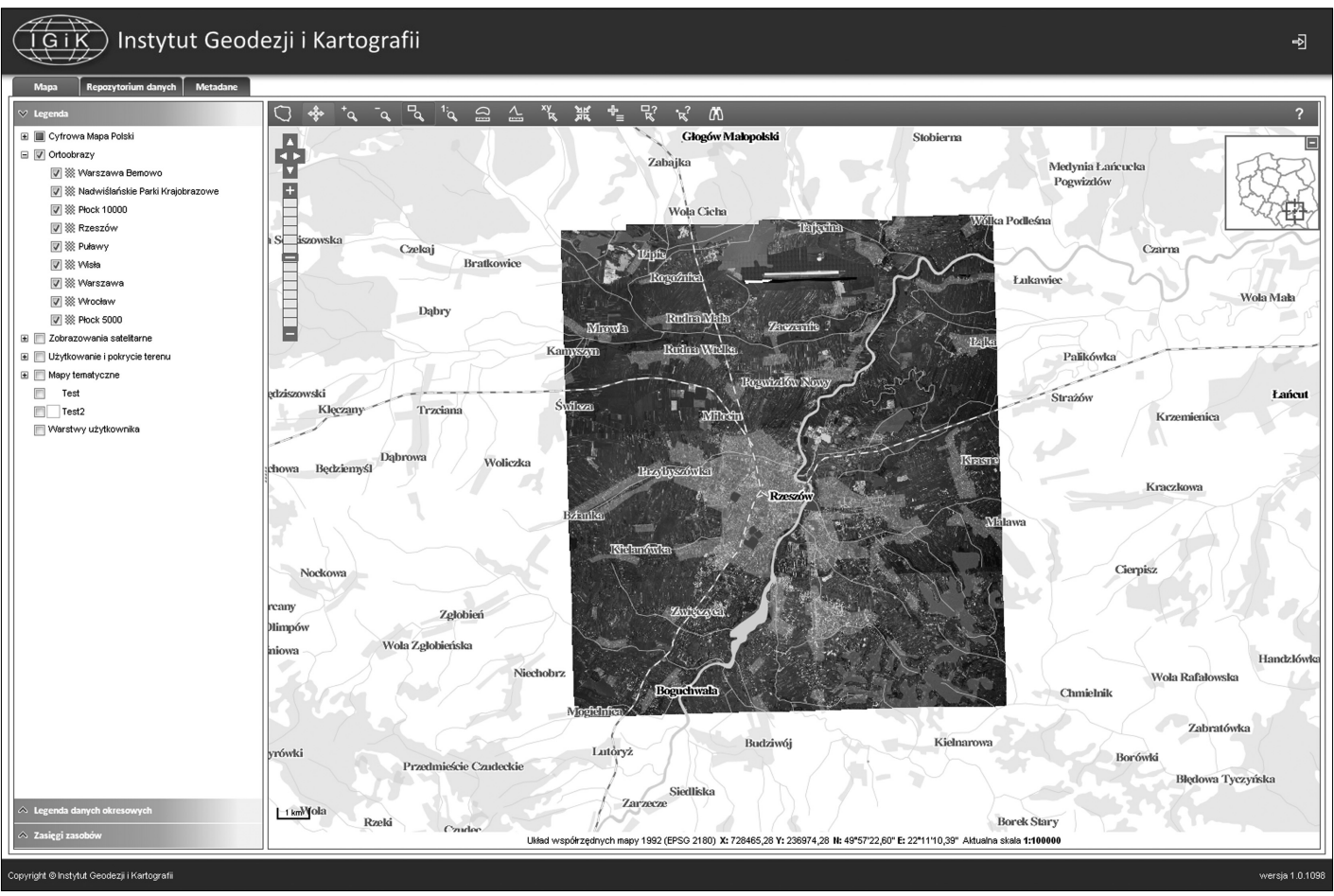

Przykład elektronicznej formy prezentacji zasobów geoinformacyjnych Instytutu Geodezji i Kartografii w Warszawie udostępnianych użytkownikom w ramach funkcjonowania systemu OGNIWO

ne, przedsiębiorcy, w tym inwestorzy krajowi i zagraniczni, administracja publiczna oraz użytkownicy indywidualni. Usługi danych przestrzennych są świadczone przez całą dobę z wykorzystaniem sieci Internet jako głównego medium komunikacyjnego. Potencjalny-
- jak wspomniano wyżej - w formie map, zdjęć lotniczych, w tym wykonanych w technikach specjalnych oraz zdjęć satelitarnych pozyskiwanych przez satelity środowiskowe, a także ich przetworzenia do postaci zbiorów tematycznych charakteryzujących stan powierzchni Ziemi. 
W celu łatwiejszego korzystania z zasobu uporządkowano go dzieląc na kilka grup:

- zasoby publikacji naukowych z zakresu fotogrametrii, teledetekcji, systemów informacji przestrzennej i kartografii komputerowej, które objęły zbiory biblioteczne, patentowe oraz wydawnictwa i wyniki prac badawczych pracowników Instytutu;

- zasoby z zakresu geodezji i geodynamiki, do których zaliczono wyniki badań prowadzonych na stacjach obserwacyjnych GNSS, wielofunkcyjnej stacji obserwacyjnej „Borowa Góra”, a także wyniki obserwacji oraz charakterystyki stanu potencjalnych pól geofizycznych dla obszaru całej Polski;

- zasoby fotogrametryczne, które objęły zdjęcia naziemne, lotnicze i satelitarne oraz wytworzone na ich podstawie produkty fotogrametryczne, takie jak: wyniki aerotriangulacji, numeryczne modele terenu, ortofotomapy i mapy sytuacyjno-wysokościowe. Do tej grupy zaliczono także punkty terenowej osnowy fotogrametrycznej oraz profile kontrolne służące do oceny dokładności geometrycznej produktów fotogrametrycznych;

- zasoby teledetekcyjne, w których ulokowano przede wszystkim zdjęcia satelitarne wykonywane przez satelity środowiskowe pracujące w widmie optycznym i mikrofalowym, a także wyniki naziemnych pomiarów i obserwacji służących weryfikacji danych satelitarnych. W tej grupie znalazły się również zbiory danych powstałe w wyniku przetworzenia zdjęć satelitarnych do postaci pozwalającej na charakterystykę roślinności, wykrywanie zagrożeń środowiska oraz ocenę ich skutków;

- zasoby wektorowe i macierzowe utworzono z baz liczących ponad 20 zbiorów danych o bardzo zróżnicowanej treści, różnym zasięgu geograficznym, formacie i sposobie udostępniania. Zbiory zaliczone do tej grupy prezentują wyniki prac naukowo-badawczych realizowanych w wielu projektach prowadzonych w Instytucie Geodezji i Kartografii;

- zasoby kartograficzne objęły zarówno mapy papierowe, jak i cyfrowe. Udostępnione mapy powstawały w wyniku realizacji różnych prac naukowych i rozwojowych oraz na zamó- wienie przedsiębiorców i administracji publicznej. Są to w większości cyfrowe mapy obrazowe (satelitarne lub fotomapy) uzupełnione o treść podkładową oraz zdigitalizowane mapy papierowe głównie przedstawiające pokrycie terenu i użytkowanie ziemi.

Analiza zasobów Instytutu została przeprowadzona według ustalonej metody, zgodnie z opracowanym wzorcem opisu, który uwzględniał między innymi takie informacje, jak: sposób prowadzenia zasobu, zakres tematyczny, zasięg przestrzenny, aktualność, zastosowany model danych, rozdzielczość przestrzenna, format danych i układ odniesień przestrzennych, a także warunki dotyczące korzystania z zasobu i historię jego powstania.

Zidentyfikowane zasoby geoinformacyjne i biblioteczne zostały podzielone na trzy podstawowe grupy:

- zasoby cyfrowe gotowe do wykorzystania (nie wymagające modernizacji),

- zasoby cyfrowe wymagające modernizacji,

- zasoby analogowe wymagające modernizacji.

Wyniki analizy i oceny zasobów dały podstawy do opracowania metody integracji i harmonizacji poszczególnych zbiorów danych przestrzennych oraz w kolejnych etapach projektu pozwoliły na przekształcenie zbiorów do uzgodnionej postaci, opisanie zbiorów metadanymi oraz udostępnienie zasobów szerokiemu gronu użytkowników.

Metodyka integracji i harmonizacji zbiorów danych gromadzonych w Instytucie uwzględnia znormalizowane podejście do modelowania informacji geograficznej opisane w normach międzynarodowych w zakresie informacji geograficznej ${ }^{1}$, dokumentach europejskiej infrastruktury informacji przestrzennej INSPIRE oraz specyfikacjach OGC. Podejście to bazuje na opracowaniu dziedzinowych schematów aplikacyjnych, katalogów obiektów, charakterystyce danych poprzez opisanie ich metadanymi, ujednoliconym opisie położenia, topologii i stosowanego systemu odniesień przestrzennych

${ }^{1}$ Polski Komitet Normalizacyjny, PN-EN ISO 19101 - 19119, Warszawa 2005-2007. 
i czasowych, spójnych słownikach i tezaurusach. Zaletą takiego podejścia była uniwersalność oraz niezależność od wykorzystanych narzędzi do gromadzenia, zarządzania i udostępniania zasobu ${ }^{2}$. W konsekwencji przyjęcie takiej metodyki zapewniło interoperacyjność zbiorów wchodzących w skład zasobu geoinformacyjnego Instytutu i umożliwiło łączenie zbiorów danych przestrzennych oraz interakcję usług danych przestrzennych bez powtarzalnej interwencji manualnej, w taki sposób, aby wynik był spójny, a wartość dodana zbiorów i usług danych przestrzennych została zwiększona ${ }^{3}$. Dla wszystkich potencjalnych użytkowników zasobu Instytutu Geodezji i Kartografii oznacza to możliwość łatwego i zautomatyzowanego kojarzenia w toku pojedynczej analizy zbiorów danych, dotyczących różnych zakresów tematycznych i pochodzących z różnych źródeł oraz opartych na różnych zestawach reguł interpretacyjnych.

OGNIWO jest systemem sieciowym tworzonym przez dwa węzły współpracujące ze sobą: centralny i internetowy. Oba węzły korzystają ze swoich zasobów komunikując się za pomocą standaryzowanych usług, są one elementami funkcjonującymi autonomiczne, tj. w taki sposób, iż wyłączenie jednego z nich nie spowoduje unieruchomienia działania pozostałego systemu. Do współpracy poszczególnych węzłów systemu OGNIWO oraz współpracy węzła internetowego $\mathrm{z}$ systemami zewnętrznymi o charakterze geoportali, zastosowana zostata architektura zorientowana na usługi (ang. Service Oriented Architecture - SOA $)^{4}$. OGNIWO zaprojektowane zostało jako tzw. systemem skalowalny, oznacza to, że istnieje możliwość zwiększania jego rozmiarów (liczby elementów składowych) zgodnie ze zwiększającą się funkcjonalnością i liczbą użytkowników.

Węzeł centralny (udostępniony pracownikom Intytutu) jest systemem gromadzenia, zarządzania i udostępniania cyfrowych zasobów geoinformacyjnych pogrupowanych $\mathrm{w}$ siedem zasobów:

1. Zasób zbiorów bibliotecznych i niepublikowanych wyników prac naukowo-badawczych i rozwojowych,
2. Zasób danych geodezyjnych i geofizycznych,

3. Zasób wyników pomiarów i obserwacji terenowych,

4. Zasób fotogrametryczny,

5. Zasób danych teledetekcyjnych obejmujących obrazy satelitarne, zdjęcia lotnicze, ortofotomapy oraz wyniki przetworzeń źródłowych danych teledetekcyjnych,

6. Zasób zbiorów wektorowych (punktowych, liniowych, powierzchniowych) i macierzowych (grid). Kluczową rolę w tym zasobie pełni baza danych - Cyfrowa mapa podkładowa Polski opracowana w skali 1:200 000 . Baza ta powstała w końcu lat 90. ubiegłego wieku w wyniku digitalizacji analogowych map topograficznych w skali 1:200 000. Stąd jej zakres tematyczny odpowiada treści mapy topograficznej. Baza jest wykorzystywana do opracowywania cyfrowych oraz analogowych map tematycznych przez pracowników naukowych. Kolejne bazy to CORINE Land Cover wraz ze zbiorami pochodnymi. Obejmują one obszar całego kraju i charakteryzują się spójną metodologią wyznaczania klas pokrycia terenu, jednolitym układem współrzędnych i formatem zapisu. Trzeci duży zbiór wśród baz danych wektorowych tworzą dane powstałe w wyniku realizacji projektów badawczych. Charakteryzują się one dużym zróżnicowaniem pod względem treści, stosowanych układów współrzędnych i form zapisu. Ich modernizacja uwzględniała między innymi aktualizację, zmianę formatu, budowę topologii. Dane macierzowe zgromadzone w postaci grid, to również zbiory będące wynikami prac naukowo-badawczych zrealizowanych przez pracowników IGiK. Włączenie tych baz wymagało ich aktualizacji oraz integracji przestrzennej z innymi zasobami.

7. Zasób kartograficzny grupuje zarówno mapy analogowe, jak i cyfrowe, które powstawały w wyniku realizacji różnych prac nauko-

${ }^{2}$ D. Gotlib, A. Iwaniak, R. Olszewski, Budowa Krajowej Infrastruktury Danych Przestrzennych w Polsce - Harmonizacja Baz Danych Referencyjnych, Wrocław 2006, s. 17-19.

${ }^{3}$ Dyrektywa 2007/2/WE Parlamentu Europejskiego, art. 3, pkt. 7.

${ }^{4}$ T. Kubik, G/S. Rozwiązania sieciowe, PWN, Warszawa 2009, s. 136-140. 
wych i rozwojowych oraz na zamówienie przedsiębiorców i administracji publicznej. Mapy $\mathrm{w}$ postaci cyfrowej to $\mathrm{w}$ większości mapy obrazowe (satelitarne lub fotomapy) uzupełnione o treść podkładową. Tematyka map analogowych z reguły jest związana z pokryciem terenu i użytkowaniem ziemi, na wielu mapach wyeksponowane są elementy związane $\mathrm{z}$ oceną stanu środowiska.

Węzeł centralny charakteryzuje się różnorodnością wykorzystywanych systemów operacyjnych, systemów do zarządzania bazami danych, specjalistycznych aplikacji, a także zróżnicowaną funkcjonalnością, typem, formatem i ilością gromadzonych danych. Zakres tematyczny, modele, typy i formaty danych gromadzonych w węźle centralnym są odzwierciedleniem zadań wykonywanych przez poszczególne jednostki Instytutu, wymagań projektów badawczo-rozwojowych oraz wykorzystywanych narzędzi informatycznych.

Zasoby gromadzone w węźle centralnym są zintegrowane i zharmonizowane, a także ujednolicone pod względem stosowanego systemu odniesień przestrzennych oraz formatu danych. Od strony funkcjonalnej węzeł centralny jest wyposażony w moduł komunikacji z węztem internetowym i zintegrowany system zarządzania cyfrowym zasobem geoinformacyjnym IGiK.

Węzeł internetowy, w odróżnieniu od węzła centralnego, do którego dostęp mają tylko pracownicy Instytutu, jest geoportalem rozbudowanym o serwer biblioteczny, poprzez który udostępniane są zasoby geoinformacyjne Instytutu, czyli dane przestrzenne i bazy danych bibliotecznych. Udostępnienie to odbywa się za pomocą zaawansowanej infrastruktury informatycznej i technologii społeczeństwa informacyjnego. W architekturze tego węzła znajduje się kilka modułów: moduł komunikacji węzła internetowego $\mathrm{z}$ węztem centralnym, moduł zarządzania danymi i metadanymi, analiz przestrzennych, a także moduły udostępniania danych w sieci Internet, bezpieczeństwa i autoryzacji oraz monitorowania węzła.

Dostęp do zasobów IGiK dla badaczy zainteresowanych historycznymi danymi przestrzennymi jest realizowany poprzez gra- ficzny interfejs przeglądarki internetowej, która komunikuje się z usługami sieciowymi danych przestrzennych. Usługi sieciowe udostępniane są zgodnie ze specyfikacjami Web Services oraz otwartymi i prawnie niezastrzeżonymi standardami. Dostęp do usług węzła internetowego poprzedzony jest za każdym razem uwierzytelnieniem i autoryzacją klienta. Opracowując zasady udostępniania cyfrowych zasobów geoinformacyjnych przygotowano opis architektury systemu OGNIWO wraz ze specyfikacjami technicznymi sprzętu i oprogramowania koniecznego do jego uruchomienia. Dla wybranych zasobów opracowano schematy aplikacyjne w języku UML, zgodnie z normami ISO i dokumentami INSPIRE. Ponadto opracowano technologię, procedury i narzędzia wspierające proces digitalizacji zasobów analogowych oraz integracji i harmonizacji istniejących już zasobów cyfrowych, a także opracowano zasady gromadzenia danych bibliotecznych.

Stronę internetową przedstawiającą idee i kolejne działania, które doprowadzity do powstania geoportalu znajduje się z poziomu strony internetowej Instytutu Geodezji i Kartografii - www.igik.edu.pl. Po wybraniu przycisku „OGNIWO” w panelu „Serwisy” lub w panelu "Projekty”, który wywołuje przekierowanie do strony geoportalu - www.ogniwo.igik.edu.pl. Natomiast stroną startową geoportalu OGNIWO jest strona internetowa http://geozasob. igik.edu.pl/. Geoportal składa się z trzech zakładek: „Mapa”, „Repozytorium danych”, „Metadane". Użytkownik rozpoczynając pracę od zasobów wyświetlanych na „Mapie” poprzez okno atrybutów może, oprócz wyświetlenia metadanych i bibliografii, wyświetlić również dany zasób na mapie, przejść do repozytorium lub biblioteki oraz pobrać plik.

System rozróżnia dwa rodzaje użytkowników: zalogowanego i niezalogowanego. Użytkownik zalogowany może korzystać ze wszystkich dostępnych zasobów danych oraz uprawniony jest do pobierania tych danych. Ten użytkownik widzi również wszystkie zasoby „Repozytorium danych". Natomiast użytkownik niezalogowany ma dostęp do części zasobów przestrzennych 
w oknie „Mapy” oraz do części zasobów w oknie „Repozytorium danych” i nie ma dostępu do funkcji „Pobierz dane”.

Uruchomienie portalu OGNIWO jako nowoczesnego sposobu udostępniania danych

\section{Literatura}

Dyrektywa 2007/2/WE Parlamentu Europejskiego, art. 3, pkt. 7.

Gotlib D., Iwaniak A., Olszewski R., Budowa Krajowej Infrastruktury Danych Przestrzennych w Polsce - Harmonizacja Baz Danych Referencyjnych. Wrocław: Wydawnictwo Akademii Rolniczej we Wrocławiu, 2006.

Instytut Geodezji i Kartografii, Studium Wykonalności projektu pt.: „Rozwój cyfrowych geoinformacyjnych już zgromadzonych i tych na bieżąco pozyskiwanych oraz połączenie go z biblioteką cyfrową umożliwia wszystkim zainteresowanym łatwy dostęp do danych bez ograniczeń czasowych.

zasobów geoinformacyjnych $i$ ich udostępnienie $w$ ramach Ogólnokrajowego Systemu Geoinformacji Naukowej Integrujacego Wiedzę Geodezyjna - OGNIWO. Warszawa: IGiK, 2010.

Kubik T., GIS. Rozwiazania sieciowe. Warszawa: PWN, 2009.

Polskie Normy: PN-EN ISO 19101 - 19119. 2005-2007. Polski Komitet Normalizacyjny, Warszawa.

\section{The National Geoinformation Science System Integrating Geodetic Knowledge OGNIWO}

\section{Summary}

The article presents the idea and the main objectives of the project: „The development of digital geospatial resources and their availability in the National Geoinformation Science System Integrating Geodetic Knowledge - OGNIWO". The project was financed in frames of the Innovative Economy Operational Programme, Priority 2. The general objective of the project is to provide permanent and secure access to the advanced information infrastructure for representatives of Polish scientific environment and enteprenuers. The system enables the use of geoinformation resources of the Institute of Geodesy and Cartography for the scientific, research, economic and educational purposes.

IGiK has some unique geoinformation resources regarding, among others. photogrammetry, remote sensing, geodesy and geodynamics or cartography, as well as resources of scientific publications and research results in this field. The result of the project is the OGNIWO geoportal that enables a wide group of various potential recipients to get access to the resources through a typical web browser. Spatial data services are delivered using the Internet as the main medium and are available for all authorized users.

Słowa kluczowe: historia kartografii, mapy topograficzne.

Keywords: history of cartography, topographic maps.

dr inż. Anna Wrochna - kierownik Zakładu Kartografii Instytutu Geodezji i Kartografii, członek zespołu realizującego projekt „Rozwój cyfrowych zasobów geoinformacyjnych i ich udostępnienie w ramach Ogólnokrajowego Systemu Geoinformacji Naukowej Integrującego Wiedzę Geodezyjną - OGNIWO”. Projekt finansowany z „Programu Operacyjnego Innowacyjna Gospodarka w ramach Priorytetu 2: Infrastruktura sfery B+R, Działanie 2.3: Inwestycje związane z rozwojem infrastruktury informatycznej nauki", (e-mail: anna.wrochna@igik.edu.pl). 